\title{
Dividend Payout Policy and Global Financial Crisis: A Study on Malaysian Non-Financial Listed Companies
}

\author{
Boo Hooi Laing*, Chan Tze Haw and Ruhani Ali
}

\begin{abstract}
Manuscript type: Research paper

Research aims: This paper examines the impact of the global financial crisis on Malaysia non-financial index firms' dividend policies.

Design/Methodology/Approach: This paper used panel data of 495 firm-year observations of Malaysian non-financial index firms from 2006 to 2016.

Research findings: Our findings indicate that firms adjust their dividend policies during the pre-crisis and post-crisis periods; more profitable and larger firms are more likely to distribute their dividend payouts, whereas firms with higher leverage are more likely to omit their dividends. Moreover, dividend policies that will increase firms' valuation are adopted in Malaysia. This is reflected in the signalling theory with evidence that higher profitability exerts a positive influence on firms' propensity to increase and/or maintain dividends over different study periods, implying that markets attach a high valuation to firms that can pay, especially during the crisis period. We also find the role of catering theory and smoothing hypothesis lost relevance in both crisis and non-crisis periods. Thus, the catering theory and smoothing hypothesis were not supported in Malaysia.
\end{abstract}

\footnotetext{
* Corresponding author: Boo Hai Laing is a Senior Lecturer at the Economics, Finance and Banking UUM College of Business, Universiti Utara Malaysia, Malaysia. Email: hlboo@uum. edu.my

Chan Tze Haw is a Senior Lecturer at the Graduate School of Business, Universiti Sains Malaysia, Malaysia. Email: thchan@usm.my

Ruhani Ali is a Professor at the Graduate School of Business, Universiti Sains Malaysia, Malaysia. Email: ruhani@usm.my
}

https://doi.org/10.22452/ajba.vol14no1.6 
Theoretical contribution/Originality: This study investigates the impact of the global financial crisis on Malaysia non-financial index firms' dividend policies. This paper suggestion can act as a catalyst to more comprehensive and detailed researches and studies on dividend policy in any economic landscapes.

Practitioner/Policy implications: This paper may also guide companies on the structure and use of dividend distribution over the precrisis, during the crisis, and post-crisis periods.

Research limitation/Implications: One limitation of the study is that the measures used for dividend payout determinants are only based on the theory investigated. These measures may not completely reflect all the payout determinants. Future research could address this limitation by employing other factors in the study of dividend policy such as inflation, economic growth, and corporate governance.

Keywords: Dividend Policy, Global Financial Crisis, Catering Theory, Signalling Theory, Smoothing Theory, Dividend Payout Option JEL Classification: G01, G35, O16

\section{Introduction}

The dividend policy is a financial decision that refers to the proportion of the firm's earnings, which will be paid out to the shareholders as dividends or retained in the firm for future growth and expansion. This implies that operating cash flow is important because managers must not only maintain sustainable dividend governance but also covers the financial status of the company's cash flow (Alkhuzaie \& Asad, 2018). Therefore, this decision is potentially very important to both shareholders and firm management, and it has been critically reviewed by academic researchers, stock analysts, and economists (Asad \& Farooq, 2009; Asad, 2011). However, the controversial issue still revolves around the importance of dividend policies to both and whether these policies have a significant impact on the firm's market value. Asad et al. (2019) agreed that various market defects, such as information asymmetry, differential taxation, transaction costs and agency issues will affect realworld capital markets. Therefore, the relevance theory holds that a firm's dividend policy influences its value. In this way, if the share price is expected to rise, the dividend should rise proportionately as well.

Globalisation is underway in nearly every country of the world. This new global economic structure has important implications for global business cycles. The growing importance of emerging countries has led 
to faster global growth. Therefore, an increase in the number of foreign investors in some emerging markets raises concern about whether they will affect corporate policies. Besides, Jeon et al. (2011) found that foreign investors, through their substantial shareholdings, lead firms to pay higher dividends. However, the 2008 financial crisis in the United States caused an economic recession in European countries, which then spread around the world, and global stock markets reacted sharply to the crisis in late 2018. Liow (2016) pointed out that the Asian stock markets have become more relevant and closely linked since co-movements with the US financial market increased following the crisis. With the continuous improvement of global corporate structure, competitiveness, and complexity, it is difficult to determine the factors that have a greater impact on dividends. So, there is no consistent reason to believe that the company has a dividend policy that serves the same purpose every time (Brown \& Martinsson, 2016).

The volatility of dividends disrupted expectations for future dividends. Researchers use various existing methods of assumptions and experience, ranging from simple to complex models, to determine the aspects that may have an impact on dividend payouts. For instance, Qammar et al. (2017) confirmed that profitability, firm size and liquidity are all positively related to dividend payment in Malaysia. On the other hand, Subramaniam and Devi (2011) found that dividend payment is negatively related to growth opportunities, the size of the board of directors and that the boards of directors do not influence Malaysia's dividend policy. The result may be due to the possibility that firms with high investment opportunities have access to other external financing options and do not depend on internal earnings to finance future investment.

Omar and Rizuan (2014) investigated the smoothness and stability of dividends of Malaysian listed companies using Lintner's (1956) model. The authors found evidence to support the signal theory, which states that when a company performs well, it can pay higher dividends. According to Jahanzeb et al. (2016), lesser growth and profitable companies in Malaysia were paying more dividends to send positive signals to the market, which may ultimately help companies to develop further. However, Kadim et al. (2020) discovered that dividend policy has no significant effect on an Indonesian firm's value.

Moreover, Sheikh et al. (2020) found that before the global financial crisis, investors in Pakistan only reacted differently to the price of gold and oil. But these investors have reacted differently to all 
macroeconomic fluctuations after the crisis. This is in line with Nguyen and Tran (2016), who pointed out that the global financial crisis provided an excellent opportunity to study dividend smoothing and signalling behaviour. Thus, various reasons have been given to explain the dividend payout options during the financial crisis. Particularly, the signalling theory and catering theory have recently received some attention as explanations for changes in the dividend behaviour of firms in developed markets (Fama \& French, 2001; Consler \& Lepak, 2016; Chesini \& Staniszewska, 2017).

Kouser et al. (2015) discovered a significant change in the characteristics of dividend payers during their research period on changes in dividend policy following the financial crisis. Laopodis and Papastamou (2016) pointed out that emerging markets have smaller capital markets, lower efficiency and are considered to have higher risks and volatility than developed markets. Hence, in an emerging economy like Malaysia, do dividend payments show unique behaviour than in developed markets? Hence, this study aims to examine whether or not the characteristics of dividend payers and non-payers are common in the Malaysian market, and whether or not these characteristics have changed over time. In particular, the impact of the 2008 global financial crisis on the linkage of dividend policy in terms of catering, signalling and smoothing concern must be investigated.

This paper investigates the effects of firm-specific factors on dividend payout options of Malaysian non-financial listed firms during the pre-crisis, crisis and post-crisis period. This study applies the multinomial regression analysis to examine the relationships between the independent variables, such as dividend premium (proxy of catering theory), profitability (proxy of signalling theory), previous year's dividend payout (proxy of smoothing hypothesis), cash flow, leverage, growth or investment opportunities, and company size.

Based on the above, this paper contributes to the related literature in two ways: first, we examine Malaysian firms' dividend policies during the pre-crisis (2006-2007), crisis period (2008-2009) and the postcrisis period (2010-2016), with a focus on estimating how Malaysian firms adjust their dividend before, during and after the global financial crisis link in the context of catering theory provided by Baker and Wurgler (2004a, 2004b), smoothing hypothesis developed by Lintner (1956) as well as signalling theory proposed by Akerlof (1970) in an emerging market setting. Second, the multinomial logistic model is used to examine the determinants of four different payout options (cut, 
increase, maintain, omit), instead of focusing on the decision to pay or not to pay as what has been done in previous studies. It is important to check these various expenditure options because the existing dividend fluctuates more frequently than the initial or missing decision (Van Dinh \& Yen, 2018).

Our panel data set consisted of 495 firm-year observations of Malaysian non-financial index firms from 2006 to 2016. A series of advanced econometrics procedure have been adopted, for instance, pairwise correlation coefficients, variance inflation factor (VIF), goodness-of-fit test, and Hausman tests. Empirical results reveal that all the independent variables have exhibited stationary behaviour and are thus applicable for the cointegration test. The test results denoted that all variables are bounded by a long-run equilibrium relationship eventually. The remainder of this paper is organised as follows. Section 2 in this study is the literature review, followed by Section 3 presenting the research methodology, Section 4 discussing the findings, and Section 5 summarising the paper.

\section{Literature Review}

\subsection{Background}

Dividend relevance and dividend irrelevance are two opposing viewpoints on the impact of dividend payments on a firm's value. Miller and Modigliani (1961) established the basis of the argument by stating that dividends and capital gains are indifferent to investors and thus have no effect on the company's value. However, research suggests that the Miller and Modigliani (MM) theory cannot exist in the real business world. Therefore, various theories have been put forward about the relevance of dividends. This phenomenon may explain why some firms prefer to pay dividends and why some investors may have their dividend preferences. This relevance theory holds that dividend policy is an important determinant of corporate strategy. Considering the literature on dividend policy debates, our null hypothesis is on the possible determinants of different payout options (cut, increase, maintain, omit) rather than concentrating on the decision "to pay" or "not to pay".

Lintner (1956) established the dividend smoothing hypothesis in his seminal work. The author found that investors prefer companies with stable dividend policy and demonstrated that this smoothing is a key 
determinant for a firm in terms of dividend payout options. Therefore, managers are more likely to maintain a stable level of dividends and are less likely to cut dividends. Akerlof's (1970) dividend signalling theory is used to explain dividend policy based on asymmetric information, then different signalling models. Miller and Rock (1985), and Bhattacharya (1979) created the well-known signalling models. According to Bhattacharya (1979), dividend changes contain information about future earnings and profitability. This study also stated that firms should seek external financing when their cash flow is insufficient to pay dividends. While Miller and Rock (1985) concluded that dividends can be a useful signal to inform investors about their future earnings, investors see an increase in dividend as a positive signal for future earnings.

Baker and Wurgler (2004a) proposed catering theory to explain how investor preferences influenced dividends decisions and/or the propensity to pay dividends. The author found that investors pay for dividends and that the demand has changed over time. Thus, dividend payments are affected by investor demand for dividends. This is consistent with the findings of ElBannan (2020), which states that dividend payouts of eleven emerging countries in Middle Eastern and North African are influenced by Fama and French (2001) dividend payer's characteristics and dividend premiums. Thereby, this proved that investors' preference for dividends affected dividend payout decisions. However, Anouar and Aubert (2016) failed to find support for the catering theory in the French market. Following this line of argument, this study hypothesised that:

$\mathrm{H}_{1}$ : A firm's propensity to pay dividends is positively related to dividend premium (PREM).

Miller and Rock (1985) proposed that managers have better information about the company's current earnings and dividends, which they then deliver to the market, demonstrating that dividend announcements are used to convey information about future profits. Furthermore, Joliet and Muller (2015) pointed out that dividend policy is important to investors as dividend increase demonstrates a positive signal about performance. Therefore, the dividend signalling hypothesis suggests that managers are reluctant to cut the dividend to signal a promising financial future for the firm (Bae Choi et al., 2014). Some Malaysian studies have also indicated that when companies perform well they can pay higher dividend payments (Omar \& Rizuan, 2014; Yusof \& Ismail, 2016). It is, therefore, hypothesised that: 
$\mathrm{H}_{2}$ : A firm's propensity to pay dividends is positively related to the firm's profitability (ROA).

Based on the smoothing hypothesis, Lintner (1956) stated that managers are unwilling to cut dividends as it has a negative impact on the stock price, and they do not raise the dividend if they do not believe the company's profitability will increase. Therefore, past dividends were found to be significant to dividend payout. The viewpoint regarding past dividend as a reference point for current dividend decisions is broadly consistent with previous studies reported by Kighir et al. (2015) in Malaysia, Yaseen et al. (2015) in Jordan, Andres and Hofbaur (2017) in the US, and Bostanci et al. (2018) in Turkey. Thus, this study proposes the following hypothesis:

$\mathrm{H}_{3}$ : A firm's propensity to pay dividends is negatively related to the past dividend (PDIV).

Fama and French (2001) clarified the characteristics of the dividend payer that have been used to explain the dividend policy over time, such as profitability, cash flow, investment opportunities (lagINV) and size. Further examination on these dividend payers' characteristics has been done by Manneh and Naser (2015), Kisava and John (2017), and AlNajjar and Kilincarslan (2018). Qammar et al. (2017) have listed the characteristics of dividend-paying companies in Malaysia as higher profitability, lower growth opportunities, lower firm risk, lower firm leverage, bigger size and share distribution. Hence, it is hypothesised that:

$\mathrm{H}_{4}$ : A firm's propensity to pay dividends is positively related to cash flow (CF).

$\mathrm{H}_{5}$ : A firm's propensity to pay dividends is positively related to a firm's size (SIZE).

$\mathrm{H}_{6}$ : A firm's propensity to pay dividends is negatively related to investment opportunities (lagINV).

According to Almansour et al. (2016) and Bashir and Asad (2018), leverage is another determinant of dividends. Rozeff (1982) pointed out that companies with high leverage levels tend to maintain a low level of dividend payments to reduce transaction costs associated with external financing. Mansuurinia et al. (2013) contend that leverage has a negative relationship to dividend payment, which has been proved by other studies (Abdulkadir et al., 2015). Kisman (2016) documented that firms with high levels of leverage are expected to pay fewer dividends 
to maintain their financial flexibility (Bulan et al., 2007). Therefore, this study hypothesises a negative relation between the firm's leverage and dividend payout ratio.

$\mathrm{H}_{7}$ : A firm's propensity to pay dividends is negatively related to leverage (lagLEV).

In 2008, the global financial and economic crisis led to a definite growth slowdown in world economies. Hence, firms tended to change their dividend policies in response to this external shock and the payout ability of firms drops during market crashes (He et al., 2012). Some previous studies have also evidenced that more dividend cuts were recorded during the financial crisis. Bliss et al. (2015) found that the dividends cutting unusually increase during the financial crisis, and companies mainly turned to reduce share repurchases as a source of funds. Similarly, Daniel et al. (2012) reported that firms tend to have a strong willingness to cut dividends due to cash shortages. Even in a period of limited access to external funds, reducing dividends is still regarded as a particularly expensive source of funds for the company. Therefore, cash ratios are an important determinant in dividend policy both during and after the financial crisis (Lai et al., 2014; Attig et al., 2016). It is, therefore, hypothesised that:

$\mathrm{H}_{8}$ : A firm's propensity to pay dividends is negatively related to the 2008 global financial crisis (CRI).

\section{Methodology}

This study uses panel data obtained from secondary resources (nonfinancial index firms listed on Bursa Malaysia as of December 31, 2016, and covered by DataStream and World Scope). The highest market value was used as part of the main sample selections (Fama \& French, 2001; Mui \& Mustapha, 2016; Zhou \& Liu, 2019). In line with previous studies, such as Fama and French (2001), Wang et al. (2016), and AlNajjar and Kilincarslan (2017) we also excluded financial companies, utility companies, negative book value companies, banks, insurance, and financial companies from our sample because these companies manage different accounting categories and rules. As proposed by Al-Najjar and Kilincarslan (2017), dividend decisions are made by individual companies; therefore, firm-level data is more suitable for our research to check company-specific choices. The firm-level data is obtained from the 
company's annual report as Bursa Malaysia requires all listed companies to submit their financial statements at the end of every financial year.

Dungey et al. (2008) stated that the US sub-prime mortgage crisis started on July 26, 2008, and thus we divided the study periods into three sub-periods. This is consistent with Abdulkadir et al. (2015), i.e., the pre-crisis period from January 1, 2006, to December 31, 2007; during the crisis period from January 1, 2008, to December 31, 2009; the postcrisis period from January 1, 2010, to December 31, 2016. Grouping the data into these three sub-periods will reveal whether the cross-market linkages between samples have changed due to the crisis (Liow, 2016).

There are 60 non-financial index components listed on Bursa Malaysia. Deesomsak et al. (2004) suggested that the data set should include at least three consecutive years of observations for observation purposes, implying that the company should be listed on the stock exchange at least in 2012. Therefore, the sample size for this study is limited to meet the requirements because it has been listed since 2006 and there is no missing accounting data available for regression analysis. However, because these data are obtained based on data availability, the final sample after deleting missing and outliers are 45 companies, totalling 495 firm-year observations.

The dependent variable in this study is the dividend payout option, and it is expected to be influenced by explanatory variables in the model, such as PREM, SIZE, ROA, lagINV, PDIV, lagLEV and CF. We also looked at how Malaysian firms adjusted their dividend payout options in response to the 2008 global financial crisis. In this case, we adopted a quantitative research design to examine the relationship of independent variables on a firm's payout options.

Figure 1 shows the dependent variable is the firms' dividend payout options that is measured as a dummy variable in various study periods with four outcome levels, $\mathrm{DIV}=1$ if dividends are cut, $\mathrm{DIV}=2$ if dividends are increased, DIV $=3$ if dividends are maintained and, DIV $=4$ if dividends are omitted. There are three different theory of dividends are included in the regression models, namely, dividend catering, dividend signalling, and smoothing hypothesis. Baker and Wurgler (2004a) proposed that the PREM is calculated by using the difference between the average price-to-book ratio of the payer and the nonpayer is another way to measure the incentives for catering. Next, in accordance with Fama and French (2001), ROA can be used to forecast the changes in both earning and profitability. This has been confirmed by Abdulkadir et al. (2015) that ROA is a measure of a company's 


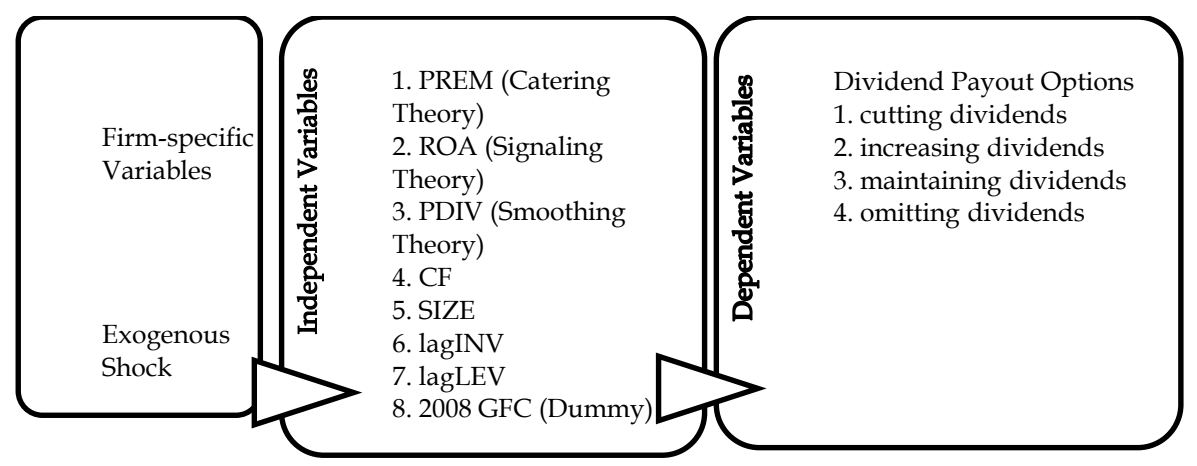

Figure 1: Research Framework

profitability, and it is widely used in explaining the dividend signalling theory (Mehta, 2012).

This research used PDIV to explain the stability of dividends as a proxy for smoothing hypothesis (Lintner, 1956). The SIZE, ROA and INV that represent the characteristics of dividend payers proposed by Fama and French (2001) were also added to the model. The previous year's market-to-book ratio was used as an indicator of lagINV in the model; while the SIZE of the firm in the model was measured as the natural log of total assets (Mui \& Mustapa, 2016; Singla \& Samanta, 2018). CF represents the cash flow of the company's liquidity, that is, the net cash flow generated from operating activities (Walkup, 2016). Next, previous year's debt for total assets was used as an indicator of lagLEV in the regression model (Mui \& Mustapa, 2016; Al-Najjar \& Kilincarslan, 2016).

As we can see the dependent variables in this research is broken into four discrete payout choices; thus, the multinomial logistic regression was employed to answer the research objective. We directly adopted the general multinomial logistic model in the following equation.

$$
\begin{aligned}
\operatorname{Ln} \frac{\operatorname{pr}(D I V=j)}{\operatorname{pr}(D I V=k)}= & \alpha_{0}+\beta_{1} P_{R E M_{i t}}+\beta_{2} R_{O} O A_{i t}+\beta_{3} P D I V_{i t}+ \\
& \beta_{4} S I Z E_{i t}+\beta_{5} C F_{i t}+\beta_{6} I N V_{i t-1}+\beta_{7} L E V_{i t-1}+\varepsilon_{i t}
\end{aligned}
$$

where: DIV = dependent variable with four outcomes;

$1=$ cut dividend, 2 = increase dividend, 3 = maintain dividend, and $4=$ omit dividend;

$\mathrm{j}=$ different outcome levels: 1,2 , and 3;

$\mathrm{k}=$ base outcome (outcome level 4 ). 


\section{Findings and Discussion}

\subsection{Descriptive Statistics of Variables}

Table 1 is devoted to present the summary statistics of variables in the regression model. After deletion of missing values and outliers, the table shows a total of 495 firm-year observations over the various study period; 90 observations for pre-crisis period; 90 observations for during crisis period; and another 315 observations for post-crisis period. As shown in Table 1, the firm payout option is a dummy variable with four outcome levels. As indicated in Table 1, the mean value of PREM increased steadily from 0.09 during pre-crisis period to 0.44 during crisis period, then to 1.47 during post-crisis period. This implies a consistent rise in the company's preference for catering to the needs of investors.

The mean value of ROA, which is approximately 87 per cent in the pre-crisis period, rise to 92 per cent during the crisis before it dropped to 86 per cent in the post-crisis period. The highest mean value was reported in time of crisis. This suggests that firms recorded declines in ROA after the crisis, and the effect of the crisis possibly extended until the post-crisis period. The mean value of PDIV increased over the different periods, showing at least $\$ 0.08$ dividend per share paid by firms during post-crisis period.

The table indicates the mean value of CF fell from 0.27 in the precrisis period to 0.24 during the crisis, and then rebounded to the highest level after the crisis of 0.31 . The mean value of SIZE, which increased

Table 1: Descriptive Statistics of Variables over the Various Study Periods

\begin{tabular}{|c|c|c|c|c|c|c|c|c|c|}
\hline \multirow[t]{2}{*}{ Variable } & \multicolumn{3}{|c|}{ Pre-crisis } & \multicolumn{3}{|c|}{ Crisis } & \multicolumn{3}{|c|}{ Post-crisis } \\
\hline & Obs & Mean & Std Dev & Obs & Mean & Std Dev & Obs & Mean & Std Dev \\
\hline PAYOUT & 90 & 2.67 & 0.89 & 90 & 2.50 & 1.07 & 315 & 2.31 & 0.96 \\
\hline DP & 90 & 0.93 & 0.25 & 90 & 0.94 & 0.23 & 315 & 0.97 & 0.18 \\
\hline PREM & 90 & 0.09 & 0.24 & 90 & 0.44 & 0.08 & 315 & 1.47 & 0.49 \\
\hline ROA & 90 & 0.87 & 0.67 & 90 & 0.92 & 0.78 & 315 & 0.86 & 0.74 \\
\hline PDIV & 90 & 0.05 & 0.13 & 90 & 0.07 & 0.13 & 315 & 0.08 & 0.15 \\
\hline $\mathrm{CF}$ & 90 & 0.27 & 0.49 & 90 & 0.24 & 0.35 & 315 & 0.31 & 0.47 \\
\hline SIZE & 90 & 13.74 & 1.57 & 90 & 13.88 & 1.55 & 315 & 14.27 & 1.50 \\
\hline lagINV & 90 & 3.24 & 4.87 & 90 & 2.77 & 4.80 & 315 & 5.29 & 12.48 \\
\hline lagLEV & 90 & 0.30 & 0.22 & 90 & 0.30 & 0.22 & 315 & 0.31 & 0.21 \\
\hline
\end{tabular}


across the different sub-periods, indicates the expansion of firms over the years. The highest mean value was reported in the post-crisis period. Thus, as measured by the natural log of total assets, the average SIZE of the firm in the post-crisis period is 14.27.

The table presents the lowest mean of lagINV was recorded in time of crisis, implying that a lack of valuable lagINV during economic downturn caused by the financial crisis. Descriptive statistics also revealed that firms listed on the Bursa Malaysia maintained at 30 per cent to 31 per cent levered across the different sub-periods, demonstrating that less than 31 per cent of Malaysian firm's total assets were financed by debt.

Table 2 presents the companies payout dividends (based on the 4 classifications) over these three different study periods. The bold line in Figure 2 indicates that the number of firms that decided to increase their dividend recorded a dramatic drop in the aftermath of the crisis, but reached its highest in 2010 (just after the crisis period). However, as illustrated in Figure 2, the number of dividend payers (cut, maintain, and omit dividends) declined during this crisis period. This signifies that the increased dividend payments during this period were the result of a reduced number of dividend payers who choose to cut, maintain, or omit their dividends.

Figure 2 and Table 2 show a varying trend during the crisis period (2008 and 2009). When the crisis was at its worst, the number of firms that decided to distribute dividends by cutting, maintaining, or omitting dividend levels increased. However, there was an initial sign of recovery in the post-crisis period (2010-2012), as most payers were more likely to increase their dividend payout after the crisis compared to the other three payout options. In comparison to dividend payer (DP) increases and dividend cuts, the number of payers who engage in maintaining and omitting payments remains relatively stable over the study period.

Table 2: Number of Non-Financial Index Constituents by Payout Options during the Pre-crisis, Crisis and Post-crisis Periods

\begin{tabular}{lcccr}
\hline Payout & Pre-crisis & Crisis & Post-crisis & Total \\
\hline Cut & 5 & 21 & 76 & 102 \\
Increase & 40 & 22 & 100 & 162 \\
Maintain & 25 & 28 & 103 & 264 \\
Omit & 20 & 19 & 36 & 75 \\
\hline Total & 90 & 90 & 315 & 495 \\
\hline
\end{tabular}




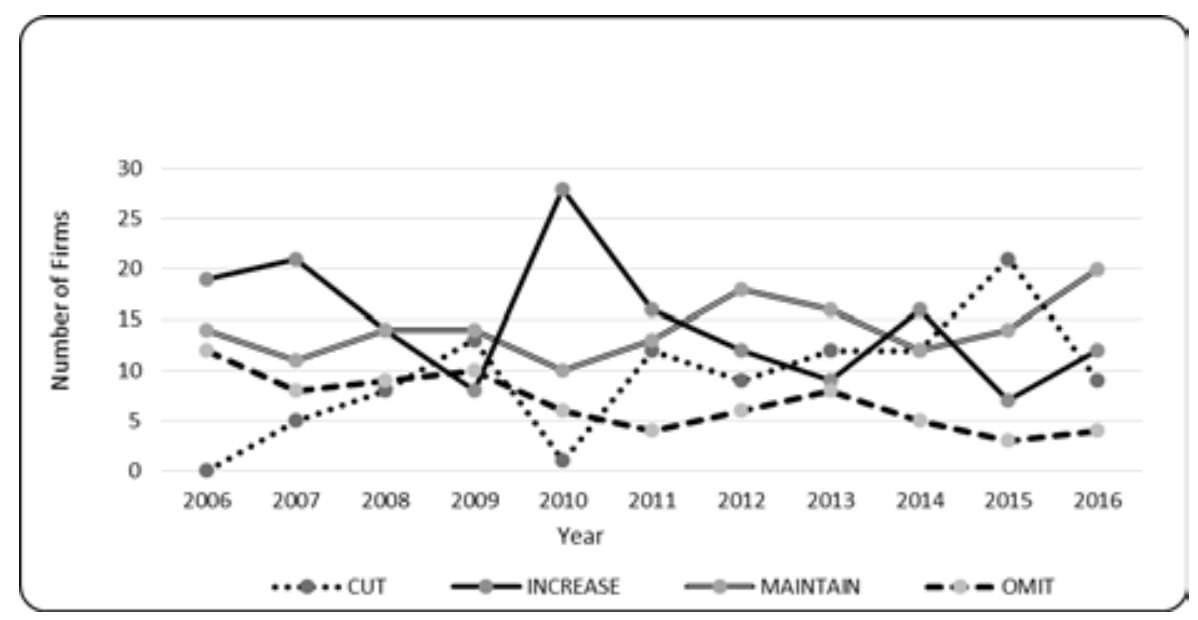

Figure 2: Dividend Payout Options of Malaysian Non-Financial Index Firms

As shown in Figure 2, an opposite trend was found between the decision to cut and or increase the dividend, which shows that most dividend payers tend to distribute their dividends in the same way during different research periods. However, the reverse trend occurred in the last two years, indicating that the recovery was not sustained. Overall, the trend during the crisis shows that dividend payments were greatly affected in the second year of the crisis. More explanation about this will be presented in the following sections.

\subsection{Regression Results}

Following that, pairwise correlation coefficients are calculated to test the correlation and potential multicollinearity between the explanatory variables used in the regression model (Brooks, 2014). The results in Table 3 shows that the highest correlations were found between SIZE and ROA with 0.65 , followed by CF and SIZE with 0.64 , and the correlation between PDIV and ROA with 0.57. Since all correlations were less than 0.7 , we can conclude that no highly correlated variables were discovered in the regression (Bryman \& Cramer, 1997).

Thereafter, the variance inflation factors (VIF) were calculated to determine the degree of the multi-collinearity present in the data results. Hair et al. (2010) pointed out that there is a problem of multicollinearity if the VIF value exceeds 10. The results in Table 4 suggest that there was 
Table 3: Pairwise Correlation Coefficients

\begin{tabular}{|c|c|c|c|c|c|c|c|c|c|}
\hline Variable & Payout & $\mathrm{Dp}$ & Prem & Roa & Pdiv & $\mathrm{Cf}$ & Size & Laginv & Laglev \\
\hline Payopt & 1.00 & & & & & & & & \\
\hline Dp & 0.03 & 1.00 & & & & & & & \\
\hline Prem & -0.12 & 0.04 & 1.00 & & & & & & \\
\hline Roa & 0.09 & 0.13 & -0.02 & 1.00 & & & & & \\
\hline Pdiv & 0.01 & 0.10 & 0.09 & 0.57 & 1.00 & & & & \\
\hline $\mathrm{Cf}$ & -0.13 & 0.07 & 0.04 & -0.27 & -0.03 & 1.00 & & & \\
\hline Size & -0.26 & 0.06 & 0.15 & -0.65 & -0.15 & 0.64 & 1.00 & & \\
\hline Laginv & -0.06 & 0.06 & 0.06 & 0.35 & 0.40 & 0.01 & -0.15 & 1.00 & \\
\hline Laglev & -0.09 & -0.04 & 0.02 & -0.05 & -0.03 & 0.21 & 0.29 & 0.16 & 1.00 \\
\hline
\end{tabular}

Table 4: Variance Inflation Factors (VIF) for Logit Model

\begin{tabular}{lcc}
\hline Variables & Variance Inflation Factors (VIF) & Tolerance value (1/VIF) \\
\hline SIZE & 3.80 & 0.26 \\
ROA & 3.35 & 0.30 \\
PDIV & 1.90 & 0.53 \\
CF & 1.83 & 0.55 \\
lagINV & 1.30 & 0.77 \\
lagLEV & 1.24 & 0.81 \\
DP & 1.07 & 0.93 \\
PREM & 1.05 & 0.95 \\
Mean VIF & 1.94 & \\
\hline
\end{tabular}

no multicollinearity because the tolerance values were less than 1.00 and the VIF did not exceed 10, indicating that there was no multicollinearity between model variables.

The results of the model fit tests are shown in Table 5 . The overall ratio $\chi^{2}$ of the model had a statistical value of 106.03 , which was statically significant at $1 \%$, indicating the overall model's goodness of fit. The Wald test, like the likelihood ratio, is used to test the null hypothesis that all parameters are equal to zero at the same time. As shown in Table 5, the Wald chi-square test statistic of 86.17 was significant at a $1 \%$ significance level; thus, we rejected the null hypothesis, demonstrating that at least one coefficient in the model influences the dependent 
Table 5: Test for Goodness of Fit

\begin{tabular}{lc}
\hline Tests & Results \\
\hline Number of observations & 495 \\
LR chi2 (27) & $106.03^{* * *}$ \\
Multinomial Model Wald chi-square & $86.17^{* * *}$ \\
PCP (per cent) & 96.36 \\
\hline
\end{tabular}

variable. Following this, the percentage of correct predictions (PCP) was computed to assessability of the model in classifying outcomes of the dependent variables.

The PCP of this research was recorded at $96.36 \%$, which is very high compared to a measure of predictive accuracy proposed by Pampel (2000) in the range of $50 \%$ to $100 \%$. The statistical evidence displayed in Table 6 shows that no significance was found among these four alternatives. Therefore, we failed to reject the null hypothesis, which indicates that the assumption of IIA holds and justifies the use of the multinomial model in this study.

Table 6: Hausman Tests and Suet-based Hausman

\begin{tabular}{lrrrrr}
\hline \multirow{2}{*}{ Tests } & \multicolumn{2}{c}{ Hausman Tests } & & \multicolumn{2}{c}{ Suet-Based Hausman } \\
\cline { 2 - 3 } \cline { 6 - 6 } & Chi2 & P $>$ Chi2 & & Chi2 & P $>$ Chi2 \\
\hline Cut & -3.16 & & & 13.19 & 0.66 \\
Increase & 2.35 & 1 & & 6.28 & 0.99 \\
Maintain & 2.51 & 1 & & 12.60 & 0.70 \\
OMIT & 0.04 & 1 & & 9.61 & 0.89 \\
MLOG1-Base Outcome & 2 & 2 & & 2 & 2 \\
MLOG2-Base Outcome & 1 & 1 & & 1 & 1 \\
\hline
\end{tabular}

\subsection{Payout Options Before the Crisis}

The estimation results from multinomial logistic regression analysis are presented in Table 7 . The likelihood ratio $\chi^{2}$ values of this model were 43.52, 46.56 and 55.51, which were statistically significant at $1 \%$. This indicates the overall fit of the model for three different sample periods. The coefficient estimates compare the likelihood of different payout options, namely, reduce dividend, increase the dividend, and maintain dividend to the likelihood of the base outcome, which is omitting 
dividends. The number of observations was 495 , with 90 observations during the pre-crisis period, 90 observations during the crisis period, and 315 observations during the post-crisis period.

The pre-crisis results revealed that the coefficient of ROA was significantly positive under two payout categories. This indicates that profitable firms prefer to increase or maintain their dividends level than eliminate dividends. Consistent with Signalling theory, firms with higher ROA have more ability to distribute dividends. The negative coefficient of PDIV under the decision contradicts the prediction of the dividend smoothing hypothesis of Lintner (1956). This implies that past dividend is not a reference point that can affect the firms' current payout decision, and the regression results show that Malaysian firms have a higher preference to omit dividends rather than increase or maintain dividends when last year's dividend payout was high, therefore failing to support smoothing hypothesis in the pre-crisis period.

Table 7 also shows that size was significant for all the different payout options relative to the decision to omit dividends. This finding suggests that larger firms are more likely to distribute dividends through any of these options (cut, increase, maintain) than not paying at all. The results show that $\mathrm{CF}$ was negatively related to the payout options under two different payout categories: dividend increasing versus dividend omitting and dividend maintaining versus dividend omitting. Thus, firms with higher $\mathrm{CF}$ level will prefer to omit dividends rather than paying by increasing or maintaining dividends. This finding is consistent with Hauser (2013), who also found that CF has no significant impact on dividend policy during the pre-crisis period. In general, the findings indicate that two of the dividend payer characteristics indicated by Fama and French (2001) are supported in the pre-crisis period.

The coefficient of lagLEV was negative and significant during the pre-crisis period, revealing that firms with higher debt levels are more inclined to omit dividends than maintaining dividend payouts. Highly levered firms may need to maintain their internal funds by lowering their dividend payments to reduce the transaction costs associated with external financing. Two variables were found to be insignificant in the pre-crisis period: dividend premium and lagINV. This indicates a lack of evidence in support of catering theory, which is in line with Anouar and Aubert (2016), who also disclosed that the catering theory is insignificant in explaining dividend payouts of the French market. Besides, lagINV was not found to be significant in explaining the Malaysian firm's dividend decision for the different outcome categories. 


\subsection{Payout Options During the Crisis}

The results in Table 7 for the crisis period indicate a shift in dividend policy during the crisis as a predictor of dividend changes during this period. PDIV became irrelevant during the crisis, implying that dividends paid in the past year will not affect dividend payout options regardless of the existence of the crisis. This is contrary to the findings of Rane and Raju (2016), which confirmed that PDIV is a significant determinant of dividend policy.

The coefficient of ROA remained positive during the crisis period, with a significant impact under two payout categories: the decision to increase dividend relative to omit dividend and the decision to maintain dividend relative to omit dividend. This indicates that Malaysian firms were more likely to increase or maintain dividend payments than to omit dividend payout, indicating that they do follow the signalling mechanism during the crisis period. This is consistent with the findings of Nguyen and Tran (2016) in the US and Malaysia.

Besides, the crisis period result illustrated that the coefficient of SIZE was significant across all payout options. The results revealed that large Malaysian firms preferred to pay dividends by cutting, increasing or maintaining them rather than omitting them, providing support for Fama and French (2001) who claimed that larger firms are more likely to pay higher dividends. This is consistent with the findings of Mui and Mustapha (2016) that also found that firm size has a significant relationship with dividend payout in Malaysia.

The findings also illustrated that only three factors found retaining their significant coefficients in the crisis period include ROA, PDIV and lagLEV. Table 7 further shows that lagLEV has a negative impact on the dividend policy. The results indicate that when the debt level is high, Malaysian firms prefer to maintain their dividend payout rather than omitting their dividend payout. This also supports the signalling theory of dividend because firms are prone to increase dividends as a signal to reassure investors about the company's prospects during a crisis period.

LagINV remained insignificant even during the crisis period. Therefore, among the characteristics of dividend payers proposed by Fama and French (2001), only lagINV was irrelevant in explaining payout choices during the crisis. This is in line with our expectations that Malaysian firms with higher ROA and larger firm size will be better able to withstand the impact of the crisis. 


\subsection{Payout Options After the Crisis}

Findings indicate a similar trend in payout policy during the crisis and post-crisis periods. Apart from dividend premium and lagINV, which became significant only once in the post-crisis period, other variables such as ROA, SIZE, and lagLEV remained unchanged over various study periods. This suggests that the impact of the crisis is still felt in the post-crisis period. Our evidence indicates considerable changes in dividend policy during the crisis, as some theories only become relevant because of the crisis, while others lose significance due to the crisis.

The post-crisis results in Table 7 show that higher dividend premiums lead to Malaysian firms omitting their dividend payout compared to increase their dividend. The result matches with Baker and Wurgler (2004b), who reported that dividend premiums in the US were mostly negative. Furthermore, the findings present that ROA retained its positive and significant coefficient after the crisis period under different payout options. Thereby, more profitable firms have a higher propensity to distribute their dividend through cutting, increasing, or maintaining than dividends omitting in the post-crisis period. This finding concurs with Yarram and Dollery (2015), who indicated that larger firms were able to distribute higher dividend due to their strength to pay dividends.

Moreover, the coefficient of PDIV was insignificant during the crisis period but became negatively significant across all payout categories, indicating that the higher the dividend paid in the previous year, the more likely these firms are to omit their dividends. The findings could be attributed to the market's recent recovery after the crisis period, which lowered the market performance. As PDIV was found to be significantly influenced by market performance (Nor et al., 2013), firms were less likely to distribute dividends after the crisis. This suggests that Malaysian firms failed to pursue the dividend smoothing hypothesis during the post-crisis period.

Also, the post-crisis results illustrated that CF was found to be insignificant during the crisis and post-crisis period, which was contrary to Hauser (2013) who suggested that CF had a significant impact on dividend policy in the post-crisis period. Additionally, Table 7 demonstrates that firm SIZE was consistently significant under all payout options over different sub-periods, indicating that larger firms were more likely to pay through the cut, increase, or maintain their dividend level than omit dividends. These findings illustrate that two of the characteristics of a dividend payer (high ROA and larger firm) 
Table 7: Multinomial Logit Model for Dividend Payout Decisions

\begin{tabular}{|c|c|c|c|c|c|c|}
\hline \multirow[t]{2}{*}{ Developed Economies } & \multicolumn{2}{|c|}{$\begin{array}{l}\text { Pre-Crisis } \\
(2006-2007)\end{array}$} & \multicolumn{2}{|c|}{$\begin{array}{c}\text { Crisis } \\
(2008-2009)\end{array}$} & \multicolumn{2}{|c|}{$\begin{array}{l}\text { Post-Crisis } \\
(2010-2016)\end{array}$} \\
\hline & Coef & $\mathrm{P}>|\mathrm{Z}|$ & Coef & $\mathrm{P}>|\mathrm{Z}|$ & Coef & $P>\mid Z$ \\
\hline \multicolumn{7}{|l|}{ Cut Dividend } \\
\hline Dividend Premium & 51.82 & 0.99 & 1.41 & 0.76 & 0.03 & 0.95 \\
\hline Profitability (ROA) & 1.96 & 0.31 & 0.73 & 0.44 & 1.59 & 0.01 \\
\hline Past Dividend & -16.93 & 0.31 & -2.31 & 0.69 & -8.39 & 0.02 \\
\hline Cash Flow & -3.45 & 0.19 & -1.37 & 0.56 & -0.53 & 0.51 \\
\hline Size & 1.90 & 0.05 & 1.51 & 0.02 & 1.19 & 0.00 \\
\hline Investment Opportunity & 0.15 & 0.58 & -0.01 & 0.97 & 0.22 & 0.03 \\
\hline Leverage & -2.66 & 0.37 & -1.04 & 0.58 & -1.46 & 0.24 \\
\hline Constant & -42.86 & 0.97 & -20.76 & 0.03 & -16.89 & 0.00 \\
\hline \multicolumn{7}{|l|}{ Increase Dividend } \\
\hline Dividend Premium & 1.03 & 0.47 & -6.16 & 0.18 & -0.91 & 0.03 \\
\hline Profitability (ROA) & 2.24 & 0.02 & 1.67 & 0.09 & 1.34 & 0.03 \\
\hline Past Dividend & -7.90 & 0.04 & 1.71 & 0.79 & -7.52 & 0.03 \\
\hline Cash Flow & -2.57 & 0.02 & -2.32 & 0.34 & -0.09 & 0.91 \\
\hline Size & 1.99 & 0.00 & 1.91 & 0.01 & 1.03 & 0.00 \\
\hline Investment Opportunity & -0.01 & 0.69 & -0.22 & 0.26 & 0.20 & 0.05 \\
\hline Leverage & -0.96 & 0.52 & -0.69 & 0.73 & -2.17 & 0.07 \\
\hline Constant & -26.81 & 0.00 & -23.35 & 0.01 & -12.64 & 0.00 \\
\hline \multicolumn{7}{|l|}{ Maintain Dividend } \\
\hline Dividend Premium & 0.11 & 0.95 & -1.35 & 0.77 & 0.09 & 0.83 \\
\hline Profitability (ROA) & 2.73 & 0.01 & 2.72 & 0.01 & 1.40 & 0.02 \\
\hline Past Dividend & -6.50 & 0.07 & -9.96 & 0.11 & -7.51 & 0.03 \\
\hline Cash Flow & -2.59 & 0.04 & -1.62 & 0.49 & -0.34 & 0.67 \\
\hline Size & 2.10 & 0.00 & 2.30 & 0.00 & 0.87 & 0.00 \\
\hline Investment Opportunity & 0.00 & 0.99 & -0.04 & 0.80 & 0.20 & 0.06 \\
\hline Leverage & -3.64 & 0.04 & -4.55 & 0.03 & -2.00 & 0.09 \\
\hline Constant & -28.37 & 0.00 & -30.54 & 0.00 & -11.83 & 0.00 \\
\hline \multicolumn{7}{|l|}{ Omit Dividend } \\
\hline Log Likelihood Chi2 & 43.52 & 0.00 & 46.56 & 0.00 & 55.51 & 0.00 \\
\hline Number of Observations & \multicolumn{2}{|c|}{90} & \multicolumn{2}{|c|}{90} & \multicolumn{2}{|c|}{315} \\
\hline
\end{tabular}


indicated by Fama and French (2001) were supported during the postcrisis period. These findings also concur with Kisman (2016) who found that larger firms would have a higher propensity to pay dividends.

On the other hand, the post-crisis results show that the lagINV found to be positive and significant under all outcome category. This implies that firms with higher lagINV were more likely to pay through dividend cuts, increase, or maintain instead of dividend omit after the crisis period. Also, Table 7 demonstrates that highly levered firms were more likely to omit dividends than to increase or maintain their dividend levels after the crisis period. Consistent with the findings of Adan and Omagwa (2018), the results imply that firms with higher lagLEV were less likely to pay cash dividends due to their intention to reserve internal funds to address serious financial constraints.

\section{Implications and Conclusion}

We investigated the factors that influenced the company's dividend payout decision in three different sub-periods using a sample of 495 firm-year observations obtained from 45 non-financial index companies over 11 years (2006 to 2016). We investigated whether dividend policy changed during the financial crisis, as well as potential explanations for the observed changes. Our evidence shows that dividend policy has changed significantly during the pre-crisis and post-crisis periods, indicating that dividend policies change during the pre-crisis and post-crisis periods due to the need to maintain financial flexibility. The findings also show that three of the dividend payer characteristics (larger firm with high ROA but fewer lagINV) identified by Fama and French (2001) are supported over the study period. The increasing level of dividend payer characteristics may have contributed significantly to Malaysian non-financial companies' upward trend in dividend payments. As a result, the ability of these firms to pay has been demonstrated to be largely unaffected by the crisis. These findings will assist investors in better understanding why companies' payout policies may shift in a volatile market environment and Malaysia's economic system.

Besides, the role of catering theory and PDIV lost relevance during the study periods, indicating that firms do not shape dividend policies to meet investors' preferences during the crisis. These findings suggest that Malaysian non-financial companies are less concerned with smoothing dividends, and that manager maybe also less responsive to investor preferences for dividends during these three sub-periods. This may 
be due to the ability of firms to maintain decreased stable dividends because of the crisis.

The empirical results have also revealed that ROA is an important determinant of dividend policy in Malaysia over various study periods. This reflects the strong support of the signalling theory, which consistently and significantly positive with dividend increasing and maintaining behaviour even during the crisis period. Moreover, the higher the leverage level, the more likely Malaysian non-financial companies are to omit their dividend payout. Thus, these firms should consider the optimal capital structure by relying less on debt financing such that managers can maintain their internal funds to resolve their debt.

Therefore, the evidence documented the importance of signalling theory and the firm's characteristics regardless of whether it is in time of distress (crisis period) or on a daily routine basis (non-crisis period) and thus fill the gap in the literature. As such, firm management should prioritise dividend policy in their financial management strategies to formulate a policy in term of gaining trust to attract investors and thus creating value for their company in the capital market. Under such circumstances, it is very important for dividend policymakers, the government and regulators to understand the factors driving changes in the dividend policy of the Malaysian stock market. This will help related parties build trust in the market and create favourable conditions for enterprises. This study can act as a catalyst to more comprehensive and detailed researches and studies on dividend policy in any economic landscapes. However, this study has limitations. It is recommended that upcoming researchers should look at other factors such as inflation, economic growth, and corporate governance in the study of dividend policy.

\section{References}

Abdulkadir, R., Abdullah, N.A.H., \& Wong, W-C. (2015). Dividend policy changes in the pre-, mid-, and post-financial crisis: Evidence from the Nigerian stock market. Asian Academy of Management Journal of Accounting and Finance, 11(2), 103-126.

Adan, F.A., \& Omagwa, J. (2018). Relationship between firm financials and dividend policy of firms listed at Nairobi Securities Exchange, Kenya. International Journal of Scientific and Education Research, 2(5), 13-30.

Akerlof, G.A. (1970). The market for "lemons": Quality uncertainty and the market mechanism. The Quarterly Journal of Economics, 84(3), 488-500. https://doi.org/10.2307/1879431 
Alkhuzaie, A.S., \& Asad, M. (2018). Operating cashflow, corporate governance, and sustainable dividend payout. International Journal of Entrepreneurship, 22(4), 1-9.

Almansour, A.Z., Asad, M., \& Shahzad, I. (2016). Analysis of corporate governance compliance and its impact over return on assets of listed companies in Malaysia. Science International, 28(3), 2935-2938.

Al-Najjar, B., \& Kilincarslan, E. (2016). The effect of ownership structure on dividend policy: Evidence from Turkey. Corporate Governance, 16(1), 135161. https://doi.org/10.1108/CG-09-2015-0129

Al-Najjar, B., \& Kilincarslan, E. (2017). Corporate dividend decisions and dividend smoothing: New evidence from an empirical study of Turkish firms. International Journal of Managerial Finance, 13(3), 304-331. https:/ / doi. org/10.1108/IJMF-10-2016-0191

Al-Najjar, B., \& Kilincarslan, E. (2018). Revisiting firm-specific determinants of dividend policy: Evidence from Turkey. Economic Issues, 23(1), 3-34. http://eprints.hud.ac.uk/id/eprint/34442/

Andres, C., \& Hofbaur, U. (2017). Do what you did four quarters ago: Trends and implications of quarterly dividends. Journal of Corporate Finance, 43, 139-158. https://doi.org/10.1016/j.jcorpfin.2017.01.003

Anouar, K., \& Aubert, N. (2016). Does the catering theory of dividend apply to the French listed firms? Bankers Markets $\mathcal{E}$ Investors: an academic $\mathcal{E}$ professional review. Group Banque. https://hal.archives-ouvertes.fr/halshs01401867/

Asad, M. (2011). Working capital management and corporate performance of textile sector in Pakistan. Paradigms: A Research Journal of Commerce, Economics and Social Sciences, 6(1), 100-114. https://doi.org/10.24312/ paradigms 060101

Asad, M., \& Farooq, A. (2009). Factors influencing KSE 100 index/share prices. Paradigms: A Journal of Commerce, Economics, and Social Sciences, 3(1), 34-51. https:// doi.org/10.24312/paradigms030102

Asad, M., Iftikhar, K., \& Jafary, A.Y. (2019). Relationship between capital structure and financial performance of textile sector companies. Kashmir Economic Review, 28(1), 39-52.

Attig, N., Boubakri, N., Ghoul, S.E., \& Guedhami, O. (2016). The global financial crisis, family control, and dividend policy. Financial Management, 45(2), 291-313. https:// doi.org/10.1111/ fima.12115

Bae Choi, B., Kang, J., \& Lee, D. (2014). Determinants and market implications of differentiated dividends in Korea. International Journal of Managerial Finance, 10(4), 453-469. https:/ / doi.org/10.1108/IJMF-11-2012-0116

Baker, M., \& Wurgler, J. (2004a). A catering theory of dividends. The Journal of Finance, 59, 1125-1165. https:// doi.org/10.1111/j.1540-6261.2004.00658.x

Baker, M., \& Wurgler, J. (2004b). Appearing and disappearing dividends: The link to catering incentives. Journal of Financial Economics, 73(2), 271-288. https:// doi.org/10.1016/j.jfineco.2003.08.001 
Bashir, A., \& Asad, M. (2018). Moderating effect of leverage on the relationship between board size, board meetings and performance: A study on textile sector of Pakistan. American Scientific Research Journal for Engineering, Technology, and Sciences (ASRJETS), 39(1), 19-29.

Bhattacharya, S. (1979) Imperfect information, dividend policy, and the bird in the hand fallacy. The Bell Journal of Economics, 10, 259-270. https://doi. org $/ 10.2307 / 3003330$

Bliss, B.A., Cheng, Y., \& Denis, D.J. (2015). Corporate payout, cash retention, and the supply of credit: Evidence from the 2008-09 credit crisis. Journal of Financial Economics, 115(3), 521-540. https://doi.org/10.1016/j.jfineco. 2014.10.013

Bostanci, F., Kadioglu, E., \& Sayilgan, G. (2018). Determinants of dividend payout decisions: A dynamic panel data analysis of Turkish stock market. International Journal of Financial Studies, 6(4), 1-16. https://doi.org/10.3390/ ijfs6040093

Brooks, C. (2014). Introductory econometrics for finance (3rd edition). Cambridge University Press.

Brown, J., \& Martinsson, G. (2016). Taxing capital, stunting growth? Capital income taxes, costly equity finance, and investment in R\&D (Working Paper, Swedish House of Finance). https:/ / doi.org/10.2139/SSRN.2506669

Bryman, A., \& Cramer, D. (1997). Quantitaive data analysis with SPSS 12 and 13: A guide for social scientists. Routledge. https://rufiismada.files. wordpress. com /2012/02/quantitative_data_12_13.pdf

Bulan, L., Subramanian, N., \& Tanlu, L. (2007). On the timing of dividend initiations. Financial Management, 36(4), 31-65.

Chesini, G., \& Staniszewska, A. (2017). The determinants of dividend policy: A comparison between firms listed on the Italian Stock Exchange and on the Warsaw Stock Exchange (2001-2014). Journal of Management and Financial Sciences, 10(30), 77-90.

Consler, J., \& Lepak, G.M. (2016). Dividend initiators, winners during 2008 financial crisis. Managerial Finance, 42(3), 212-224. https://doi. org/10.1108/MF-07-2015-0187

Daniel, N.D., Denis, D.J., \& Naveen, L. (2012). Sources of financial flexibility: Evidence from cash flow shortfalls (unpublished working paper). Drexel University and University of Pittsburgh.

Deesomsak, R., Paudyal, K., \& Pescetto, G. (2004). The determinants of capital structure: Evidence from the Asia Pacific region. Journal of Multinational Financial Management, 14(4-5), 387-405. https://doi.org/10.1016/j.mulfin. 2004.03.001

Dungey, M., Fry, R., González-Hermosillo, B., Martin, V.L., \& Tang, C. (2008). Are financial crises alike? (IMF Working Paper WP/10/14). 1-58.

ElBannan, M.A. (2020). Does catering behavior persist? Evidence on dividend sentiment in emerging financial markets. International Review of Economics E Finance, 69, 350-373. https://doi.org/10.1016/j.iref.2020.06.016 
Fama, E.F., \& French, K.R. (2001). Disappearing dividends: Changing firm characteristics or lower propensity to pay? Journal of Financial Economics, 60(1), 3-43. https:// doi.org/10.1016/S0304-405X(01)00038-1

Hair, J., Black, W., Babin, B., \& Anderson, R. (2010). Multivariate data analysis. Prentice-Hall, Inc.

Hauser, R. (2013). Did dividend policy change during the financial crisis? Managerial Finance, 39(6), 584-606. https://doi.org/10.1108/03074351311 322861

He, Z., Li, K., \& Lu, R. (2012). Catering to the illusion of nominal share prices: Evidence from the high dividend payout of mutual funds in China. http://www. ccfr.org.cn/cicf2012/enrc_demo.php

Jahanzeb, A., Memon, P.A., Tunio, J.A., \& Shah, S.S.A. (2016). Impact of corporate governance and firm-level control variables on dividend policy of service trade sector of Malaysia. Journal of Economic and Social Development, $3(2), 102-111$.

Jeon, J.Q., Lee, C., \& Moffett, C.M. (2011). Effects of foreign ownership on payout policy: Evidence from the Korean market. Journal of Financial Markets, 14(2), 344-375. https://doi.org/10.1016/j.finmar.2010.08.001

Joliet, R., \& Muller, A. (2015). Dividends and foreign performance signaling. Multinational Finance Journal, 19 (2), 77-107.

Kadim, A., Sunardi, N., \& Husain, T. (2020). The modeling firm's value based on financial ratios, intellectual capital and dividend policy. Accounting, 6(5), 859-870. https://doi.org/10.5267/j.ac.2020.5.008

Kighir, A.E., Omar, N.H., \& Mohamed, N. (2015). Corporate cash flow and dividends smoothing: A panel data analysis at Bursa Malaysia. Journal of Financial Reporting and Accounting, 13(1), 2-19. https://doi.org/10.1108/ JFRA-09-2013-0072

Kisava, Z.S., \& John, F.M. (2017). Determinants of dividends payout and policy used in emerging economies: Evidence from Turkey. Business and Economic Research, 7(2), 362-374. https://doi.org/10.5296/ber.v7i2.11921

Kisman, Z. (2016). Disappearing dividend phenomenon: A review of theories and evidence. Transylvanian Review, 24(8), 1286-1293.

Kouser, R., Luqman, R., Yaseen, A., \& Azeem, M. (2015). Dividend payout policy and financial crisis: Evidence from the Life Cycle Theory. Pakistan Journal of Commerce and Social Sciences (PJCSS), 9(2), 583-598.

Lai, H.Y., Abdul Aziz, A.R., \& Chan, T.K. (2014). Effect of the global financial crisis on the financial performance of public listed construction companies in Malaysia. Journal of Financial Management of Property and Construction, 19(3), 246-263. https://doi.org/10.1108/JFMPC-02-2014-0002

Laopodis, N.T. \& Papastamou, A. (2016). Dynamic interactions between stock markets and the real economy: evidence from emerging markets. International Journal of Emerging Markets, 11(4), 715-746. https://doi.org/10.1108/ IJoEM-12-2015-0253 
Lintner, J. (1956). Distribution of incomes of corporations among dividends, retained earnings, and taxes. The American Economic Review, 46(2), 97-113.

Liow, K.H. (2016). Global financial crisis and cyclical co-movements of Asian financial markets. Journal of Property Investment $\mathcal{E}$ Finance, 34(5), 465-495. https://doi.org/10.1108/jpif-03-2016-0018

Manneh, M.A., \& Naser, K. (2015). Determinants of corporate dividends policy: Evidence from an emerging economy. International Journal of Economics and Finance, 7(7), 229-239. http:/ / doi.org/10.5539/ijef.v7n7p229

Mansuurinia, E., Emamgholipour, M., Rekabdarkolaei, E.A., \& Hozoori, M. (2013). The effects of board size, board independence and CEO duality on dividend policy of companies: Evidence from Tehran Stock Exchange. International Journal of Economy, Management and Social Sciences, 2(6), 237-241.

Mehta, A. (2012). An empirical analysis of determinants of dividend policy evidence from UAE companies. Global Review of Accounting and Finance, $3(1), 18-31$.

Miller, M.H., \& Modigliani, F. (1961). Dividend policy, growth, and the valuation of shares. Journal of Business, 34(4), 411-433. https://doi. org/10.1086/294442

Miller, M.H., \& Rock, K. (1985). Dividend policy under asymmetric information. The Journal of Finance, 40(4), 1031-1051. https://doi.org/10.1111/ j.15406261.1985.tb02362.x

Mui, Y.T. \& Mustapha, M. (2016). Determinants of dividend ratio: Evidence from Malaysian public listed firms. Journal of Applied Environmental and Biological Sciences, 6(IS), 48-54.

Nguyen, X.M., \& Tran, Q.T. (2016). Dividend smoothing and signaling under the impact of the global financial crisis: A comparison of US and Southeast Asian Markets. International Journal of Economics and Finance, 8(11), 118-123. https://doi.org/10.5539/ijef.v8n11p118

Nor, F.M., Ibrahim, I., \& Rashid, M. (2013). Exposure to investor sentiment in Malaysia: Services versus manufacturing stocks. Global Business $\mathcal{E}$ Economics Anthology, 1, 239-248.

Omar, N., \& Ridzuan, S. (2014). Financial deceitful trick through dividend smoothing. Procedia - Social and Behavioural Sciences, 145, 300-307. https:/ / doi.org/10.1016/j.sbspro. 2014.06.038

Pampel, F.C. (2000). Logistic regression: A primer (quantitative applications in the social sciences). SAGE Publications.

Qammar, R., Ibrahim, Y., \& Alam, M.M. (2017). Dividend payment behavior: Evidence from Malaysia. Asian Journal of Multidisciplinary Studies, 5(3), 37-46.

Rane, A., \& Raju, G.A. (2016). Dividend smoothing and implications of Litner model - An empirical analysis of Indian auto sector. International Journal of Multidisciplinary Research (IJ MR), $6(8$ (II)), 121-127.

Rozeff, M.S. (1982). Growth, beta and agency costs as determinants of dividend payout ratios. Journal of Financial Research, 5(3), 249-259. 
Sheikh, U.A., Asad, M., Ahmed, Z., \& Mukhtar, U. (2020). Asymmetrical relationship between oil prices, gold prices, exchange rate, and stock prices during global financial crisis 2008: Evidence from Pakistan. Cogent Economics \& Finance, 8(1), 1-20. https:/ / doi.org/ 10.1080/23322039.2020.1757802

Singla, H.K., \& Samanta, P.K. (2018). Determinants of dividend payout of construction companies: a panel data analysis. Journal of Financial Management of Property and Construction, 24(1), 19-38. https://doi.org/10.1108/ JFMPC-06-2018-0030

Subramaniam, R., \& Devi, S.S. (2011). Corporate governance and dividend policy in Malaysia. In 2010 International Conference on Business and Economics Research, vol. 1, pp. 200-207. IACSIT Press.

Van Dinh, N., \& Yen, N.T.H. (2018). Testing effects of changes in earnings to dividend actions of listed firms on Vietnamese stock exchanges using the multinomial logistic regression model. VNU Journal of Science: Economics and Business, 34(2), 44-53. https://doi.org/10.25073/2588-1108/ vnueab. 4155

Walkup, B. (2016). The impact of uncertainty on payout policy. Managerial Finance, 42(11), 1054-1072. https:/ / doi.org/10.1108/MF-09-2015-0237

Wang, M.-H., Ke, M.-C., Lin, F.-Y., \& Huang, Y.-S. (2016). Dividend policy and the catering theory: Evidence from the Taiwan Stock Exchange. Managerial Finance, 42(10), 999-1016. https:/ / doi.org/10.1108/MF-05-2015-0132

Yarram, S.R., \& Dollery, B. (2015). Corporate governance and financial policies: Influence of board characteristics on the dividend policy of Australian firms. Managerial Finance, 41(3), 267-285. https://doi.org/10.1108/MF-032014-0086

Yaseen, H., Omet, G., \& Khalaf, B.A. (2015). Dividend policy of Jordanian firms: Stability tests and survey results. International Business Research, 8(8), 72-78. https:// doi.org/10.5539/ibr.v8n8p72

Yusof, Y., \& Ismail, S. (2016). Determinants of dividend policy of public listed companies in Malaysia. Review of International Business and Strategy, 26(1), 88-99. https:/ / doi.org/ 10.1108/RIBS-02-2014-0030

Zhou, X., \& Liu, Y. (2019). The motivation and identification of listed companies with large stock dividends. In Proceedings of the 2019 International Conference on Modeling, Simulation, Optimization and Numerical Techniques (SMONT 2019). Atlantis Press. https://doi.org/10.2991/smont-19.2019.55 